\title{
Train-the-Trainer Video on the Deliberate Night Attack
}

\author{
Jean L. Dyer \\ U.S. Army Research Institute
}

Infantry Forces Research Unit

Scott E. Graham, Chief

U.S. Army Research Institute for the Behavioral and Social Sciences 5001 Eisenhower Avenue, Alexandria, Virginia 22333-5600

February 1998

$\begin{array}{lc}\text { Army Project Number } & \text { Personnel Systems and } \\ \text { 20262785A790 } & \text { Performance Technology }\end{array}$

Approved for public release; distribution is unlimited. 